STUDIES IN POPULAR CULTURE

Women drinking out in Britain since the early twentieth century

DAVID W. GUTZKE

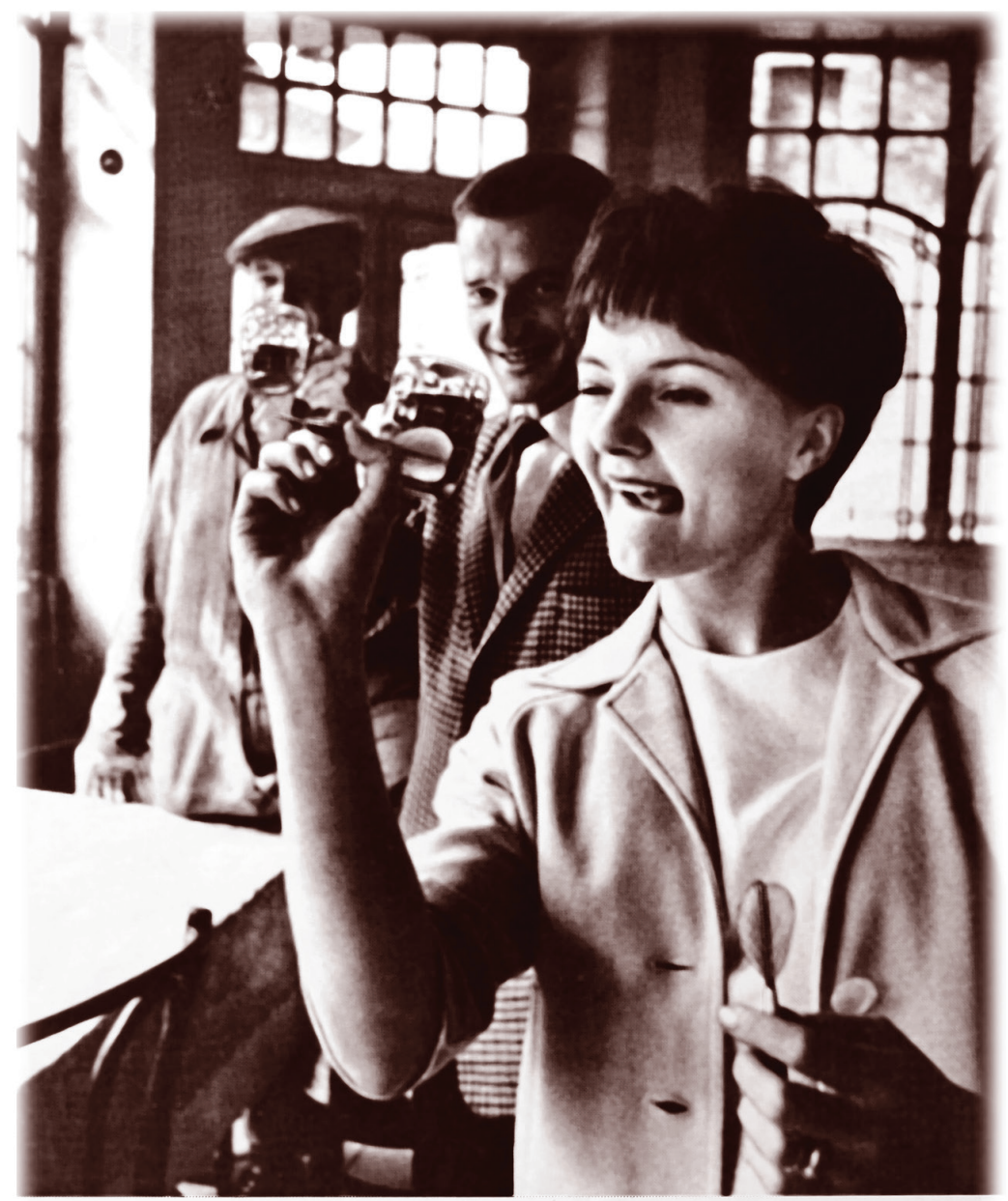

Who said girls can't play darts? I enjoy a glass of beer at the local and we've been here quite often, but today is the first time I've ever played darts. It's easy. That first one was just for practice. Now I'm concentrating This time I'm going to hit the board-I know it!

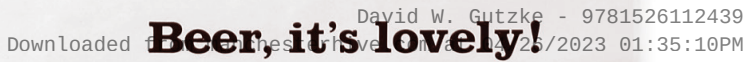




\section{Women drinking out in Britain since the early twentieth century}

\section{MANCHESTER 1824}

Manchester University Press 


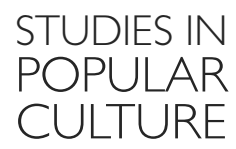

General editor: Professor Jeffrey Richards

\section{Also published in this series}

Christmas in nineteenth-century England Neil Armstrong

Healthy living in the Alps: the origins of winter tourism in Switzerland, 1860-1914 Susan Barton

Working-class organizations and popular tourism, 1840-1970 Susan Barton

Leisure, citizenship and working-class men in Britain, 1850-1945 Brad Beaven Leisure and cultural conflict in twentieth-century Britain Brett Brebber (ed.)

The British Consumer Co-operative Movement and film,

1890s-1960s Alan George Burton

British railway enthusiasm lan Carter

Railways and culture in Britain lan Carter

Darts in England, 1900-39: a social history Patrick Chaplin

Relocating Britishness Stephen Caunce, Ewa Mazierska, Susan Sydney-Smith and John Walton (eds)

Holiday camps in twentieth-century Britain: packaging pleasure Sandra Trudgen Dawson

History on British television: constructing nation, nationality and collective memory Robert Dillon

The food companions: cinema and consumption in wartime Britain, 1939-45 Richard Farmer

Songs of protest, songs of love: popular ballads in eighteenth-century Britain Robin Ganev

The BBC and national identity in Britain, 1922-53 Thomas Hajkowski

From silent screen to multi-screen: a history of cinema exhibition in Britain since 1896 Stuart Hanson

Smoking in British popular culture, 1800-2000 Matthew Hilton

Juke box Britain: Americanization and youth culture, 1945-60 Adrian Horn

Popular culture in London, c. 1890-1918: the transformation of entertainment Andrew Horrall

Horseracing and the British, 1919-39 Mike Huggins

Popular culture and working-class taste in Britain, 1930-39: a round of cheap diversions? Robert James

Scotland and the music hall, 1850-1914 Paul Maloney

Amateur film: meaning and practice, 1927-77 Heather Norris Nicholson

Films and British national identity: from Dickens to Dad's Army Jeffrey Richards

Cinema and radio in Britain and America, 1920-1960 Jeffrey Richards

Looking North: Northern England and the national imagination Dave Russell

The British seaside holiday: holidays and resorts in the twentieth century John K. Walton 


\title{
Women drinking out in Britain since the early twentieth century
}

\section{DAVID W. GUTZKE}

\author{
Manchester University Press \\ Manchester and New York
}


Copyright () David W. Gutzke 2014

The right of David W. Gutzke to be identified as the author of this work has been asserted by him in accordance with the Copyright, Designs and Patents Act 1988.

Published by Manchester University Press

Oxford Road, Manchester MI3 9NR, UK

and Room 400, 175 Fifth Avenue, New York, NY 10010, USA

www.manchesteruniversitypress.co.uk

Distributed exclusively in the USA by

Palgrave Macmillan, 175 Fifth Avenue, New York,

NY I00I0, USA

Distributed exclusively in Canada by

UBC Press, University of British Columbia, 2029 West Mall,

Vancouver, BC, Canada V6T IZ2

British Library Cataloguing-in-Publication Data

A catalogue record for this book is available from the British Library

Library of Congress Cataloging-in-Publication Data applied for

ISBN 9780719052644 hardback

First published 2014

The publisher has no responsibility for the persistence or accuracy of URLs for any external or third-party internet websites referred to in this book, and does not guarantee that any content on such websites is, or will remain, accurate or appropriate.

Typeset in Adobe Garamond with Gill Sans display by Koinonia, Manchester 


\section{STUDIES IN POPULAR CULTURE}

There has in recent years been an explosion of interest in culture and cultural studies. The impetus has come from two directions and out of two different traditions. On the one hand, cultural history has grown out of social history to become a distinct and identifiable school of historical investigation. On the other hand, cultural studies has grown out of English literature and has concerned itself to a large extent with contemporary issues. Nevertheless, there is a shared project, its aim, to elucidate the meanings and values implicit and explicit in the art, literature, learning, institutions and everyday behaviour within a given society. Both the cultural historian and the cultural studies scholar seek to explore the ways in which a culture is imagined, represented and received; how it interacts with social processes; how it contributes to individual and collective identities and world views, to stability and change, to social, political and economic activities and programmes. This series aims to provide an arena for the cross-fertilization of the discipline, so that the work of the cultural historian can take advantage of the most useful and illuminating of the theoretical developments and the cultural studies scholars can extend the purely historical underpinnings of their investigations. The ultimate objective of the series is to provide a range of books which will explain in a readable and accessible way where we are now socially and culturally and how we got to where we are. This should enable people to be better informed, promote an interdisciplinary approach to cultural issues and encourage deeper thought about the issues, attitudes and institutions of popular culture.

Jeffrey Richards 
David W. Gutzke - 9781526112439

Downloaded from manchesterhive.com at $04 / 26 / 2023$ 01:35:10PM via free access 